\title{
DEMÔNIOS E DIABRURAS NO REINO DO LEVIATÃ
}

Wilson Alves de Paiva (UEG)

wap@usp.brewp@riotapajos.com.br

Resumo: $O$ presente texto procura ressaltar a importância da obra Leviatã, de Thomas Hobbes. A figura mitológica do grande monstro marinho é evidenciada como uma metáfora para introduzir a idéia de um poder estranho ao domínio teológico, que poderia ser explorado para o benefício ou malefício do homem. Bem utilizada por Hobbes em suas reflexões sobre a criação do Estado, a metáfora aterroriza a Igreja e abre caminhos para outras figuras inquietas da história do pensamento ocidental, cujas idéias foram tidas como heréticas e demoníacas. À parte a repercussão que teve o Leviatã, no fundo não é uma obra de cunho totalitário, mas faz coro aos escritos de outros "demônios" que ajudaram a configurar o mundo moderno, dentro de uma perspectiva liberal. Assim sendo, a obra serve de referência para repensarmos a realidade atual, sobretudo a brasileira, quando os desmandos da política colocam em risco de vida nosso Leviatã.

Palavras-chave: Hobbes, Leviatã, estado moderno, política.

\section{DEMÔNIO E DIABRURAS NO REINO DO LEVIATÃ}

É bastante comum a idéia de que a Idade Média foi um período de "trevas" no campo científico e filosófico. Há fatos e imagens numa quantidade suficiente para se ter uma visão um tanto quanto pessimista da produção intelectual desse período histórico. As fogueiras da Inquisição são exemplos claros do domínio da Igreja sobre a produção do conhecimento 
e nada encorajadoras aos que alimentavam pensamentos contraditórios.

Entretanto, a atividade intelectual não foi tão incipiente quanto parece, e, longe de ter sido insipiente, a produção intelectual do Medievo revela uma intensa curiosidade para com os fenômenos naturais e uma inquietante atividade de pesquisa nas universidades existentes. Vale dizer que, aos professores, era concedida uma relativa liberdade para suas elucubrações filosóficas e, de certa forma, uma tolerância para com a expressão de suas idéias, desde que se limitassem ao mundo natural. Basta citar alguns nomes como o dominicano Alberto Magno (1193-1280), professor de Tomás de Aquino (1227-1274), que defendeu a coexistência pacífica entre a ciência e a religião; o franciscano Roger Bacon (1214-1294), que aprofundou os estudos de ótica e defendeu a observação da natureza e a experimentação. A Universidade de Oxford, na Inglaterra, já era um centro de agregação desses estudiosos e dali saíram dois nomes de importância capital para a teoria política. Refiro-me aos franciscanos Dans Scot (1266-1308) e Guilherme de Ockham cujos trabalhos ousaram contestar o poder do Papa sobre os governantes seculares, sobretudo a idéia comum de que o "trono de Pedro" reservava a plenitudo potestatis em quaisquer assuntos da cristandade. Frade franciscano, Guilherme de Ockham, criador da teoria da Navalha de Ockham, foi filósofo da lógica, teólogo escolástico e político inglês. Conhecido como o "doutor invencível”, nasceu na vila de Ockham nos arredores de Londres, na Inglaterra, em 1285, e dedicou seus últimos anos ao estudo e à meditação num convento de Munique, onde morreu em 3 ou 4 de abril de 1349 (ou 1350), provavelmente vítima da peste negra. Umas de suas maiores contribuições foram os escritos políticos nos quais tomou posição contra o Papado de Avinhão (cidade francesa sede da Igreja entre 1309 a 
1378) e a política expansionista e hierocrata dos papas, dando um grande passo à separação da Igreja e o Estado. É evidente que foram excomungados, perseguidos e duramente repreendidos pelo príncipe eclesiástico e por outros pensadores que compartilhavam com a lucrativa e muito confortável posição de hegemonia política nas mãos da Igreja.

Quando levantamos questões pertinentes à estrutura do corpus do conhecimento e do processo investigativo para sua elaboração, sobretudo do período medieval, duas figuras devem ser colocadas em jogo: a do lector e a do auctor. Em uma palestra a filólogos, depois publicada com o título Leitura, leitores, letrados, literatura, Bourdieu (1990) explora muito bem a importância de cada uma para a leitura e interpretação da realidade. Sua reflexão principal diz respeito ao modo como a pesquisa deve ser realizada e o nível de criação que o intelectual é capaz de avançar. Tomando a classificação para os propósitos desse texto, nomes como os de Ockham servem de exemplo para demonstrar que, nos meandros da "leitura" medieval, o papel de lector, isto é, o de mero comentador ou leitor de referências, em alguns casos propiciava uma ação de pesquisador capaz de atingir o status de um auctor - quem lê, relê e interpreta os textos (hermenêutica) ou os ritos e/ou fenômenos vários (semiologia) através da construção original de um discurso novo (epistemologia). Não é à toa que muitos deles foram chamados de hereges ou, nos casos mais extremados, de demônios, cujas "diabruras" intelectuais provocaram rupturas, perseguições e até guerras.

Nesse aspecto, tanto a patrística como a escolástica desenvolveu, através de seus cânones, uma verdadeira arte da leitura. As limitações dogmáticas evidentemente não permitiram maiores vôos; no entanto algumas contribuições filosóficas propiciaram releituras significativas, sobretudo a filosofia de 
Tomás de Aquino. $\mathrm{O}$ aquinate teve a ousadia de empreender a adaptação do pensamento aristotélico ao cristianismo, dando uma guinada à razão como campo semi-autônomo em relação à revelação divina. Mas coube a Guilherme de Ockahm a ruptura e o discurso de um verdadeiro auctor, pois o envolvimento do frade franciscano inglês com as conturbadas relações políticas de seu tempo propiciou um discurso novo, um discurso de valorização da autoridade civil e da ação direta do Estado.

Contudo, o que poderíamos chamar de "revolução copernicana" no campo político não foi elaborada na Escolástica Tardia ou mesmo durante o Renascimento. Esse epíteto deve ser creditado ao filósofo inglês Thomas Hobbes (1588-1679), cujo materialismo e mecanicismo levaram-no a conceber uma instância política de regulação do poder e das relações sociais fora dos domínios eclesiásticos. Sua obra pode, em muitos aspectos, ser considerada como a culminância dos debates e reflexões empreendidas pelos escolásticos e por tantos "demônios” que ao longo dos séculos medievais intentaram trilhar por semelhantes caminhos.

Mesmo valendo-se de uma argumentação teológica, Hobbes consegue redigir um fundamentado discurso em defesa de um poder laico. Seu estilo rococó de ordenação das idéias tem a ver com a linguagem necessária para sua época: não podemos esquecer que Hobbes se dirigia, em grande parte, a eclesiásticos e homens de fé num ambiente ainda muito influenciado pela simbologia cristã. Ao escrever sua obra Leviatã, a linguagem e as figuras bíblicas são evocadas para ilustrar suas reflexões, despertando a atenção dos estudiosos, e também como forma de legitimação de seu esforço perante as autoridades eclesiásticas e acadêmicas. E, nesse aspecto, sua especial analogia com o monstro marinho descrito no Livro de Jó, no Velho Testamento, permite uma análise que vai além da simples metáfora 
e demonstra que o "demônio" de Devonshire conhecia tanto as Escrituras Sagradas quanto às potencialidades reais que a figura poderia projetar no cenário filosófico e político.

O texto bíblico é bastante recheado de figuras místicas que incorporam a idéia do mal. No entanto, desde seu primeiro livro, o Gênesis, deparamo-nos com situações que sugerem não apenas a existência, mas também um universo de coexistência dessas figuras no mesmo plano da existência humana. No Éden, por exemplo, a serpente aborda sorrateiramente a mulher a fim de induzi-la ao pecado e, tendo conseguido seu intento, é expulsa do paraíso, mas permanece com vida e passa a habitar as mesmas imediações que o casal de humanóides. Mesmo no Exodo não faltam serpentes, e nos livros poéticos dos Salmos, volta e meia, dragões, monstros marinhos e outros animais são evocados como antípodas ao plano divino. É dessa natureza a figura enigmática e amedrontadora descrita no livro de Jó: "Na terra não há coisa que se possa comparar, pois foi feito para estar sem pavor. Todo o alto vê; é rei sobre todos os filhos de animais vivos" (Cap. 41, v. 33,34).

Denominado de Leviatã, a grande serpente marinha, monstro possuidor de características superiores e instrumentos de domínio, poder e destruição, essa figura mitológica serviu de metáfora ou talvez profecia, para sinalizar aos homens os perigos e os benefícios de uma dominação concebida pela criatividade humana e, pelo mesmo artifício, entronada no governo do mundo dos homens. Percebe-se, nessa metáfora, o adiantamento de algumas questões morais e também políticas que seriam discutidas somente alguns séculos depois.

Todavia, a semente lançada, ou seja, a idéia de um poder absoluto fora da esfera teocrática que permanecesse em seus domínios (mar) e com o qual pudéssemos estabelecer pactos em nosso favor, foi muito bem aproveitada na seara da 
emergente filosofia inglesa. Mais precisamente na pessoa de Thomas Hobbes que, diante do poder avassalador da Igreja ao longo da Idade Média e das intolerâncias de sua época, ousou rejeitar a submissão da esfera política à religiosa e passou a defender ardentemente o contrário, isto é, a detenção do poder por parte de um artificium humano que pusesse inclusive a autoridade eclesiástica sob seu comando. Como diz Heck (2004, p. 21), "A crítica de Hobbes ao pensamento político clássico é derivada da substituição do gesto criador bíblico pelo moderno fiat lux contratualista, gerador da vontade política de um árbitro soberano". O que significa mudar radicalmente a fonte da autoridade e da legitimidade do poder, isto é, colocar nas mãos do homem o poder criador e regulamentador da ordem social, negado pela Igreja que insistia em ter o domínio sobre as duas esferas: a temporal e a espiritual.

$\mathrm{Na}$ verdade, a luta aguerrida do filósofo inglês é, em maior proporção, contra a força religiosa que deteve por séculos a plenitudo potestatis e, o que é pior, a primazia na interpretação dos textos sagrados, principalmente aqueles que a beneficiavam e ampliavam seu domínio. Exemplo disso é a leitura que a Igreja fez de passagens bíblicas, como a metáfora dos dois gládios (Lucas 22:35-38) e a de Mateus 16:19 que diz: "Eu te darei as chaves do reino dos céus e tudo o que ligares na terra será ligado nos céus, e tudo o que desligares na terra será desligado nos céus". A interpretação materialista e, por conseguinte, política dessa última gerou uma controvérsia que durou séculos e proporcionou uma aguerrida disputa pelo poder. No entanto, permanecia no imaginário social, e até mesmo nas reflexões teóricas de muitos estudiosos, uma ordem política ainda atada às estruturas do poder eclesiástico.

A frieza da racionalidade de Hobbes e o utilitarismo presente em suas propostas tinham como alvo precípuo, o 
rompimento com essa velha estrutura e o estabelecimento de uma nova ordem social fundada, principalmente, na legitimidade de um pacto entre indivíduos livres e soberanos. Temos em Hobbes, portanto, uma nova teoria do Estado para a qual o poder não tem origem divina e cujo direito não se estabelece pela força, mas a força pelo direito. Eis porque são desconexos ao pensamento hobbesiano tanto a sociabilidade natural aristotélica quanto o jusnaturalismo estóico-cristão. Mais desconexo ainda é o aristotelismo cristianizado de Tomás de Aquino que vê na realidade sensível o efeito de uma causa divina e, portanto, a fonte do conhecimento humano (Aquino, 2004). E isso faz dele talvez o fundador da filosofia política moderna e o principal coveiro da teocracia medieval. Na construção de seu edifício teórico, Hobbes contou com um intenso burburinho seiscentista e setecentista em torno do papel do Estado na vida pública. Por um lado, os clássicos representados, sobretudo, pelas repúblicas italianas, alimentavam a idéia de uma república ciceroniana reconstruida na Europa e defendiam que uma vida efetiva vivida por homens honrados ainda era uma possibilidade (Tuck, 2001). Por outro lado, o ceticismo punha em dúvida a validade dos princípios morais e revelava a realidade da política moderna a qual consistia, segundo Tuck, na manipulação, no engano e na intimidação.

O que Hobbes faz é cutucar as feridas de uma metafísica exausta, moribunda (Heck, 2004, p. 12) e incoerente, que se revelou incapaz de uma defesa racional e inteligente contra as investidas de "demônios" mais antigos, como Euclides e Galileu, a não ser pela intolerância e pela perseguição. Mas não é o único. Pois até mesmo os "anjos" que se lançaram à tarefa de por compressas e aplicar medicamentos, acabaram mal vistos pelos arcanjos de batina e tidos como heréticos. Desde o 
século XIII, o misticismo humanista de Eckart (1260-1327) já pregava Deus como um ser absorvido no conceito de compreensão. Mais próximo ao tempo de Hobbes e provavelmente uma de suas fontes, Nicolau de Cusa (1401-1464) aprofundou o tema principal da teologia filosófica - o que seria Deus e como seria concebido - defendendo uma posição que posteriormente Hobbes viria a adotar: a idéia do Deus abscôndito, inacessivel e inconcebível. Para piorar, o demônio-rei da modernidade - tomando a expressão de Leo Strauss (Apud Tuck, 2001, p. 127) - defende uma explicação materialista dos eventos bíblicos, propõe uma leitura mecanista da realidade, aceita as implicações da ciência natural moderna e ainda, sobretudo no Leviatã, faz clara separação entre o reino de Deus e o reino dos homens. Vale a pena ouvi-lo quando diz:

Reino de Deus nos escritos divinos, e especialmente nos sermões e tratados devocionais, é mais comumente interpretado como um gozo eterno nos céus, posterior a esta vida; um Reino de Glória e, às vezes, (para o bem dessa felicidade) de santificação, o qual também é chamado de Reino da Graça; mas nunca de monarquia, ou seja, o poder soberano de Deus sobre todos os assuntos a serem tratados pelos homens, o que é a significação própria de reino. (Leviathan, p. 271)

O suficiente para ter sido rejeitado pelo corpo eclesiástico e temido por sua irreverência, mas não o bastante para ter sido reputado como ateu pessimista, defensor aguerrido de um Estado totalitário e tão cético quanto Descartes (1596-1650). Pode até haver uma aproximação entre Hobbes e Descartes, principalmente quanto à ênfase de se "pensar o mundo real como sendo essencialmente distinto do modo como o experimentamos" (Tuck, 2001, p. 69). Mas, ao contrário do plano cartesiano, o pensador inglês não recorre aos postulados teológicos e à racionalidade pura para construir sua episteme. 
Seu edifício teórico é construído sobre uma base empírica dinâmica cujo eixo de compreensão é o movimento. Nada é estático, e o conhecimento se realiza na relação que se estabelece entre nossas percepções sensíveis e os corpos moventes. E se não existe uma verdade clara e objetiva do mundo externo, seu ceticismo se torna tão relativista que, do ponto de vista moral, acaba num beco sem saída. Se todos podem fazer o que lhe parecer melhor, o conflito é inevitável, e uma guerra de todos contra todos é uma conseqüência natural.

Não obstante, o filósofo político inglês salta sobre esse aparente pessimismo e oferece como solução o grande Leviatã - talvez a grande aposta hobbesiana e sua manifestação de otimismo quanto à política e ao reino dos homens. Sua proposta evoca a idéia de uma autoridade comum para submeter os julgamentos privados a uma decisão soberana. Apesar do nome, o Leviatã não simboliza um poder totalitário e, colocado em prática, talvez não chegasse a ser uma sociedade de estado mínimo, liberal, individualista ou, na visão de MacPhearson (1979), uma sociedade de mercado possessivo; mas, com certeza, seria um regime mais brando que o militarismo de Pinochet no Chile, a ditadura cubana ou o imperialismo estadunidense. Fazendo referência a esse último, basta lembrar que, como Kant, Hobbes defende a paz entre as nações e a soberania absoluta do Estado, além de defender também uma posição contratual na qual as estruturas do poder não podem ameaçar a liberdade do homem. Diferente do contratualismo rousseauniano, para o qual o Soberano está acima de qualquer coisa, na opinião de Hobbes, é ilegítimo atentar contra a vida, por exemplo, mesmo partindo do poder absoluto.

Se for assim, por que o Leviatã é tão assustador? Para tentar uma explicação, primeiro, a criação hobbesiana é uma resposta ao despotismo eclesiástico e aos governos absolutos da 
Antiguidade e da Renascença; e, segundo, como deixa claro no capítulo 14, o vínculo das palavras nunca foi forte suficiente para refrear a ambição e as demais paixões humanas. Ou seja, é preciso um poder absoluto e coercitivo para garantir o bom funcionamento da sociedade, que vai além da simples vontade e da expressão verbal ou o escrito dos contratos. Além do mais, se no estado natural a humanidade é uma selva e o homem um lobo, logo, estabelecer a paz, garantir a sobrevivência e buscar a felicidade não são apenas necessidades primárias e condições sine qua non da ordem civil, como também um direito natural de todos, mesmo que para sua garantia seja necessário o poder da espada. Para que isso ocorra, o filósofo inglês desloca a soberania absoluta do deus imortal para localizá-la no deus mortal que concebe em sua grande obra: "é criado pelo artifício humano o grande Leviatã, chamado Comunidade ou Estado, (Civitas no latim) que é tão somente um homem artificial; contudo, dotado de maior estatura e força” (Leviathan, p. 7).

Como um organismo vivo, criado por um fiat humano nos moldes do fiat divino: "Façamos o homem à nossa imagem, conforme a nossa semelhança”" (Gênesis, 1:26) etc, sua existência corpórea estabelece-se pela união das células - os indivíduos - e é positivada pelo contrato social. O sopro divino que deu vida ao barro é substituído pela soberania do ato pactuador que concede ao corpo inerte a alma vivificadora. Os magistrados e os demais servidores públicos são a cartilagem e a juntura necessária para a união dos órgãos que, auxiliadas pelos nervos e tendões, promovem a recompensa e a punição. Talvez tenha sido esse discurso carregado de referências bíblicas e de opinião sobre a religião que tornaram Hobbes tão assustador.

No plano democrático, o pensamento de Hobbes se complementa em Rousseau, para quem o athma desse organismo só pode ser a Vontade Geral, isto é, a vontade popular pela qual 
o povo exerce sua soberania. Entretanto, tendo em vista que o "demônio" inglês precedeu ao genebrino, suas idéias políticas abriram uma via de reflexão pela qual muitos outros trilharam e que pavimentaram o pensamento político moderno para a separação entre a Igreja e o Estado.

O Leviatã é, portanto, o símbolo máximo da ciência política hobbesiana. Por ele o filósofo responde aos ataques dos intelectuais de Oxford e promove uma ruptura no pensamento político de Aristóteles, aceito até então, transformando a causa (sociedade política) em telos. E, por fim, cria uma alternativa lógico-racional para retirar o poder das mãos da Igreja. Aliás, esse conjunto simbólico alternativo só foi possível a partir do plano em que Hobbes se colocou para concebê-lo: o plano diabólico. O termo dia-bólico vem do grego clássico - dia-bállein - que significa lançar algo para longe, lançar fora ou desagregar. Diferente de Lúcifer, que foi precipitado dos céus pela força divina, ou ainda de Lutero (1483-1546), excomungado pela hierarquia romana, foi o próprio Hobbes que se diabolizou recusando seguir a carreira eclesiástica do pai, lançando-se aos estudos humanistas e produzindo sua "heresia" pela qual recebeu vários títulos, dentre eles o de herético e ateu. Só assim o "monstro de Malmesbery", como também foi chamado, pode brindar a humanidade com seu simbolismo político. O termo sim-bólico vem, igualmente, do grego clássico sym-bállein que significa lançar (bállein) junto (syn), ${ }^{1}$ ou seja, projetar algo de forma conjunta e que haja uma interligação entre as coisas lançadas, convergindo suas forças num objetivo só. Exatamente como é projetado o artifício leviatânico.

Vários teóricos políticos setecentistas (entre eles Grotius e Locke) desejaram ver um sistema no qual Estado e Igreja fossem desatrelados, e que todos fossem livres e partícipes de uma realidade engendrada apenas pelo Estado. Amedrontados pela 
teocracia romana e pela moral calvinista (a qual enviara Grotius ao exílio), evitaram as diabruras cometidas por outros, como Hobbes, que não escondeu seu materialismo e arriscou-se em projetar uma espécie de teologia negativa. Sugerindo mais que uma simples crítica ao paganismo, o diabólico pensador chega a dizer que os deuses dos gentios foram criados por causa do próprio medo que o ser humano tem em relação ao desconhecido (Leviathan, p. 72). Quanto ao imortal God, diz ele no Cap. XII:

Mas o reconhecimento de um Deus eterno, infinito e onipotente, pode ter surgido do desejo que o homem tem de conhecer as causas naturais dos corpos. (...) Desde a matéria sem forma, chamada caos, até o céu, o oceano, os planetas, o fogo, a terra e os ventos foram tidos como deuses. (...) Mas onde Deus mesmo plantou, por revelação sobrenatural, a religião, fez para si um reino particular. (...) Quando forem incapazes de provar a divina revelação, que a religião que procuram preservar seja suspeita e (sem o medo do gládio civil) contradita e rejeitada.

Apesar de ter sido descrito como "um confuso ateísmo cristão" por alguns de seus críticos, o Leviatã não chega a tanto. Todavia, desenvolve um minimalismo religioso que exclui as formalidades sacramentais e defende como princípios universais as máximas do cristianismo primitivo. $\mathrm{O}$ que Hobbes visualiza é uma religião natural cujo deus se revela como criador impessoal, do qual a mente humana não pode captar suas formas e essência. Algo que poderia ser denominado de fideísmo minimalista. Crença que, mutatis mutandis, está também bem presente no discurso do vigário saboiano de Rousseau e nas reflexões dos socialistas do início do século XIX. Se o deus de Rousseau seria mais um guia da consciência, uma voz interior a sussurrar os ditames e os desígnios da Natureza, o de Hobbes vem a ser, tão somente, o criador das leis naturais e o referencial máximo de nossas consciências individuais. Fato que não o faz mais temível e mais 
asqueroso para a Igreja que o cidadão de Genebra. $\bigcirc$ Emílio, por exemplo, foi condenado pelo Parlamento francês e pelo arcebispo de Paris. Para tristeza do patriótico genebrino, até sua cidade natal fez coro aos censuradores condenando sua obra. François Grasset (1723-1789), livreiro da cidade suíça de Lausanne, escreve-lhe para dar notícias da repercussão de seu tratado:

Não sorria meu muito honrado compatriota, quando lhe disser que vi queimar em Madrid, na igreja principal dos Dominicanos, num domingo, à saída da missa cantada e na presença de um grande número de imbecis e ex cathedra, o seu Emílio sob a forma de um volume in quarto! $\mathrm{O}$ que teve precisamente o efeito de levar vários fidalgos espanhóis e todos os embaixadores de cortes estrangeiras a adquiri-lo por qualquer preço, ou mandá-lo vir pelo serviço de posta. (Citado por HAZARD, 1996, p. 134)

Porém, é bastante conveniente ressaltar que por mais perigoso que esse fideísmo minimalista tenha sido, não pode ser confundido ou comparado com o minimalismo utilitarista e aparente encontrado nos cultos religiosos na atualidade - sobretudo nos neopentecostais - nos quais a dissimulação, o jogo das aparências e o desejo intenso pela prosperidade material subjugam as máximas do cristianismo primitivo e os princípios éticos conquistados pela humanidade até então. $\mathrm{O}$ ataque dos "demônios" medievais e modernos procurava pelo menos salvaguardar uma essência que hoje "anjos" e "pastores" vilipendiam gananciosamente.

De volta ao contexto do gentleman inglês, a turbulenta Europa do século XVII, não eram mais as bruxas que estavam soltas, porque haviam sido quase todas queimadas pelas fogueiras da Inquisição. Eram os próprios demônios que procuravam criar uma outra realidade em todos os campos da vida humana, diante da pouca munição do poder eclesiástico. Estava sendo fermentada uma arqueologia que resgatava o valor do homem 
e a força de sua vontade. Descartes interioriza, por meio do Cogito, o ponto de partida do conhecimento, da interpretação e da nomeação. Em Hobbes, o sujeito perde um pouco dessa primazia ontológica quando é criada a representação governativa soberana. No entanto, o deus mortal não deixa de ser fruto do empreendimento do sujeito, de sua intelectualidade e de sua vontade, bem como ainda estabelecido para o bem-estar do mesmo. Como diz RIBEIRO (2004, p. 218): "Para Hobbes, o Estado deveria ser um todo sem fissura. Qualquer falha nas suas juntas constituiria uma brecha pela qual a doença e mesmo a morte se infiltrariam”.

Se o homem acaba sendo um mero objeto na realidade leviatânica perdendo sua primazia para a própria representação, há uma saída muito interessante no universo de seu nominalismo que se coaduna com o surgimento da dessemelhança, no século XVII: Diferente do deus imortal e invencível, o Leviatã é um mortal God. Não sei se isso é sua força ou sua fraqueza, vantagem ou desvantagem. Do ponto de vista maquiaveliano é, sem dúvida, uma fraqueza. Mas, tomando o ponto de vista do próprio Hobbes, a desvantagem vira vantagem para os cidadãos caso o empreendimento não dê certo. Se se degringolam as intenções primeiras e o Soberano venha a atentar contra a vida de seus súditos, por exemplo, está perdida sua legitimidade e pode ser decomposto por seu criador. Ou seja, se é mortal, deve sucumbir quando não cumpre o que foi estabelecido pelo pacto, porque, certamente, perde sua razão de ser. Solução ontológica, porque acaba colocando no artifício humano e nas mãos dos cidadãos a condição de efetuar a sangria, promover a cura ou eliminar o Leviatã.

Entretanto, a história infelizmente tende a demonstrar que essa ontologia não passa de quimera. A grande serpente aumentou seus domínios com a colonização, reforçou sua es- 
trutura orgânica com as revoluções burguesas e pôde usar suas garras no estatismo soviético e chinês, sua força destruidora no regime nazista e seu poder de fogo nos inúmeros confrontos e lutas pelo poder mundial e controle das fontes energéticas, como no caso da invasão do Iraque realizada pelos Estados Unidos. Tudo isso com o menor respeito para com a dignidade humana, pois em muitos conflitos a população civil é prejudicada e muitas vezes dizimada pela letalidade do poder bélico. Exemplo disso é o confronto entre Israel e o grupo islâmico Hizbollah no Sul do Líbano. Como no mundo natural uma possível luta de bestas eliminaria uma grande quantidade de pequenos peixes, os mísseis, tanto de um como de outro lado, têm atingido crianças e velhos numa proporção que relembra a barbárie do passado.

Para além disso, o capital, um monstro mais próximo das figuras apocalípticas, tem-se levantado do mesmo mar e assenhoreado da serpente numa proporção que até Posseidon, o deus dos mares da mitologia grega, teria inveja. Personificado nas grandes corporações transnacionais, o capital financeiro mundial tem promovido uma nova ordem global cuja lógica se organiza e se desenvolve com vistas a formar uma governança supra-estatal, um poder com forças suficientes para ditar as regras e impor sua vontade tornando-se o que Hardt \& Negri (2001, p. 11) chama de "Império", isto é, uma substância política capaz de regular as permutas globais e, inclusive, chegar a "governar o mundo" (Idem, ibidem). Comparando o velho imperialismo com a nova forma de comando global, dizem os autores (Idem, p. 12 e 13):

O imperialismo era, na verdade, uma extensão da soberania dos Estados-nação europeus além de suas fronteiras. (...) Onde quer que deitasse suas raízes, a soberania moderna construía um Leviatã que cobria como um arco seu domínio social e impunha 
fronteiras territoriais hierárquicas, para fiscalizar a pureza de sua identidade e para excluir tudo o que representasse o outro. (...) Em contraste com o Imperialismo, o Império não estabelece um centro territorial de poder, nem se baseia em fronteiras ou barreiras fixas.

Sobre as ondas ideológicas do "fim da história", ideal bem divulgado por Fukuyama (1998), o novo monstro nada por mares, rios e canais de forma quase soberana. É imprescindível dizer "quase", porque, para muito além das fronteiras do Leviatã ou até mesmo dentro delas, outras bestas emergem das profundezas do mundo marinho e estarrecem o mundo com sua jurássica ossatura. $O$ fanatismo e o terrorismo são exemplos claros dessa ameaça, pois advogam uma volta ao passado e a imposição de uma "verdade" única como forma única de se estruturar a sociedade e configurar o comportamento humano.

Felizmente, o novo imperialismo enfrenta também as investidas de demônios menos problemáticos, mas não menos incômodos ao surfe da grande besta. Trata-se, evidentemente, daqueles que pensam uma ordem alternativa pela via da valorização da sociedade civil, das forças populares e das organizações não-governamentais. Uma casta um tanto quanto angelical, cujas diabruras (permitam o paradoxo) procuram a promoção do ser humano e o desenvolvimento de seu bemestar. Na linha da soberania do povo, pensada por Rousseau, o Fórum Social Mundial pode representar o espaço por excelência para se pensar uma nova ordem ou o que muitos chamam de "um outro mundo possível" (Teivainen, 2003). Se não chega a ser um verdadeiro empowerment do que Gramsci denomina em suas obras de "sociedade civil", pelo menos o FSM oferece uma abertura para as possibilidades, para as novas idéias, para o sonho e até mesmo para repensar as velhas fórmulas e respostas que viam na tomada do poder do Estado, a única via 
de transformação e revolução social. Exemplo disso é a proposição de se prover uma nova realidade sem, contudo, tomar o poder do Estado (Holloway, 2003), defendida pelas edições mais recentes do Fórum. Gadotti, um dos demônios mais sutis e versáteis, diz que:

Só podemos revolucionar o nosso modo de existir no planeta interferindo na lógica, no espírito invisível do capital. Gastar todas as nossas energias combatendo o capitalismo é inútil. Passamos muito tempo combatendo o "sistema" capitalista. Quanto mais o combatemos, sem alternativas, mais ele se fortalecerá; quanto mais combatermos os sistemas capitalistas sem outra lógica, mais ele fortalecerá a sua lógica, mais manhas e artimanhas ele encontrará para se defender. Ele só pode ser transformado, "superado", pela introdução de uma outra lógica, como alternativas viáveis econômico-político e socialmente viáveis. É o que nos tem ensinado nossa "velha" dialética. (Gadotti, 2006, p. 11).

A atual movimentação ardorosa de idéias diabolizantes tem provocado um dilema um tanto quanto inusitado. $\mathrm{O}$ discurso do fortalecimento da sociedade civil rompe com as idéias tradicionais de Estado, com a lógica governamental a qual estamos acostumados e até mesmo com a idéia de estado ampliado de Gramsci. O que se advoga sob o espírito do Fórum não é a ampliação do poder, mas a mudança de seu lócus. Ou seja, o que se projeta sutilmente no concílio forense é uma revolução, uma subversão com vistas a redimensionar a vida social e, por conseguinte, fundir a auctoritas e a potestas em favor do povo, numa espécie de novo contrato social cuja soberania se manifeste na dinâmica das organizações civis e no consenso de suas propostas. Entretanto, o problema não reside somente na introdução de uma lógica não capitalista, como defende Gadotti (loc. cit.), mas também na introdução de uma lógica não estatal. Difícil de ser concebida, a idéia nos remete ao comunitarismo 
rousseauniano porque defende um estilo de vida meio pastoril, um tanto quanto festivo que, em alguns aspectos, pode ser comparado ao segundo estágio da evolução humana, ou seja, à Idade do Ouro, descrita pelo genebrino em seu diabólico Segundo Discurso. Apesar do valor dessas idéias e do brilhantismo intelectual de seus autores, lamentavelmente nenhuma região do planeta tem desenvolvido ou preservado esse estilo de vida, excetuando algumas pequenas comunidades autóctones. $O$ fato é que, dadas as condições estruturais da sociedade moderna, dificilmente algum grupo social conseguiria realizar o autogoverno sem a força do Estado. Ainda que moribundo, o Leviatã parece ser um mal necessário, mesmo no território de um outro mundo possivel. Dessa forma, a mudança seria realizada apenas passo a passo, na somatória das pequenas e grandes diabruras, e dependeria substancialmente das alianças, dos pactos e acertos que puderem ser estabelecidos em favor de uma nova realidade.

Comentando a perspectiva de dois pensadores, Sá (2000, p. 97) discute essa problemática afirmando que:

Contra os modernos e atualíssimos leviatãs Jean-Jacques Rousseau nos indica a possibilidade de rever o atual contrato e desejar a construção de um novo pacto social que não seja determinado prioritariamente pela lógica da propriedade privada, mas, ao contrário, seja iluminado por um conjunto de normas universais que tenham por finalidade liberar os seres humanos de todas as formas de opressão, dominação, alienação e aviltamento.

Mas diante da condição utópica mesmo desejável do pensamento do filósofo de Genebra, Sá (idem, ibidem) continua dizendo: "Acreditamos que, atualmente, a teoria da justiça de John Rawls e o seu conceito de maximin podem servir de parâmetro para que se comece a pensar sobre os princípios éticos que devem orientar este novo pacto". A sociedade atual 
reclama uma verdadeira concertación, que amplie os espaços de participação popular e venha criar múltiplos canais de relacionamento político, pelos quais a população se sinta mais próxima do poder e, dessa forma, possa acompanhar as discussões de seus projetos. No entanto, paira um receio de que uma nova pactuação engendre algo pior que o velho Leviatã. Em todos os casos é imprescindível um rigor ético no estabelecimento de suas cláusulas, uma vez que a sangria que debilita o grande monstro é provocada principalmente pelas navalhas da corrupção. Uma ética universal do ser humano (Freire, 2001) se faz necessária a toda e qualquer ação política. Como o imperativo categórico ${ }^{2}$ kantiano ou a voz da consciência ${ }^{3}$ de Rousseau, a ética universal freireana serve como instrumento pedagógico ao processo de construção de novas realidades.

Que tipo de trama é possível tecer no plano de um novo pacto? É possível uma organização social sem o Estado? É possível a vivência em comum sem o rigor da lei e a força da justiça? Ou, em outras palavras, é possível promover uma nova realidade sem a espada? A alternativa de Hobbes era uma construção bem arquitetada, teoricamente fundamentada e uma resposta muito original e criativa aos problemas de sua época. Tanto em Hobbes quanto em Rousseau o minimalismo religioso funciona como um horizonte ético e um fundo moral. Qual é a moral das novas idéias? O princípio terra, como gaia, de Boff, é suficiente? Não é reducionista, materialista? Uma vez que o materialismo dialético matou a subjetividade, reprimiu a religião e obstruiu grande parte da cultura humana em favor de uma pretensa "cultura proletária”, não parece ser a resposta adequada.

Não estamos, quando discutimos um novo espaço sem o Estado, criando outro Leviatã ou decretando sua morte sem, contudo, oferecer uma alternativa real? A idéia de sociedade civil pode significar uma alternativa viável? Seria ela um aban- 
dono do marxismo ou uma releitura do mesmo? Kenneth Strike (1989), filósofo estadunidense, critica os "marxistas culturais", entre outros, por afastarem-se do hard core (cerne teórico) marxista. Mas, no caso dos movimentos civis sob o espírito do FSM, não seria um retorno ao verdadeiro marxismo, uma vez que Karl Max defendia a eliminação do Estado? Dessa forma, estaria a solução dentro do próprio Estado, isto é, em sua reestruturação e fortalecimento, ou fora dele? São questões que se colocam tanto aos hereges quanto aos devotos que não concordam com o status quo.

Parece um beco sem saída. Se a resposta perpassa os meandros estatais, torna-se urgente, como defendem Patomäki \& Teivainen (2004), reformar as instituições multilaterais, como a ONU (Organização das Nações Unidas), o FMI (Fundo Monetário Internacional) e o BM (Banco Mundial), possibilitando maior participação dos países subdesenvolvidos e a redistribuição do poder em sua organicidade, de forma a ampliar a participação democrática tanto dos países como da sociedade através de organizações civis. Talvez um conjunto de instituições democráticas globais possa fazer frente ao poder avassalador do capital e das corporações transnacionais. No entanto, o fortalecimento do Estado pode retroagir o processo histórico e repetir experiências amargas do passado. Por outro lado, se a resposta está no fortalecimento de organizações não-estatais, até hoje nenhuma experiência demonstrou a viabilidade desse projeto. Se as diabruras do FSM evocam tal possibilidade, tal heresia, no sentido que Bourdieu emprega (1990), carece de maior fundamentação teórica, maiores discussões, maior elaboração de sua heterodoxia com pressupostos menos utópicos.

No diálogo de Deus com Jó, é possível perceber certa advertência quanto ao modo de se relacionar com o monstro marinho: "Fará ele concertos contigo ou o tomarás por escravo 
para sempre? (...) Os teus companheiros farão dele um banquete, ou o repartirão entre os negociantes?" (Jó, cap. 41: 46) É o questionamento que se coloca a nós nos dias de hoje: o que se fará com o Estado? Do ponto de vista econômico, continuará sendo um banquete para o capital internacional e os banqueiros? Do ponto de vista político, continuará sendo repartido por oligarquias que se perpetuam no poder e por políticos profissionais que usam a máquina estatal a seu belprazer, usufruindo as benesses da Casa Grande enquanto o resto da população padece na Senzala?

Como ser moral e organismo jurídico fundado na soberania do povo, o Estado precisa atuar sempre no âmbito do pacto, do concerto, dentro de sua legitimidade representativa. Até que se possa inventar outra coisa, como têm tentado os intelectuais acima citados, a grande criação hobbesiana se propõe a isso com seu absolutismo liberal. $\mathrm{O}$ aspecto absolutista tem a ver com a validade das leis e o poder legítimo do soberano. Quanto ao aspecto liberal, tem a ver com as garantias da individualidade e da própria condição humana em seu direito a autoconservação, à proteção e à dignidade. Itens praticamente esquecidos pelos leviatãs da atualidade que, mesmo regulamentados por uma Constituição garantidora de direitos, como o Leviatã brasileiro, preferem o domínio e a sordidez dos desmandos.

Infelizmente o tempo não está favorável para os demônios que pensam alternativas utópicas e/ou viáveis ao status quo, como o fizeram Hobbes e os demais hereges do passado. Pelas nuvens sombrias que pairam sobre o mar do grande Leviatã, estamos mais para uma casta de demônios muito mais perigosos; mais parecem harpias famintas, orks saídos do filme O Senhor dos Anéis ou dementadores da série Harry Potter, prontos a atacar e devorar inescrupulosamente o pouco que sobra do vigor e da beleza desse animal. Como enfrentá-los é o tema 
que deve pautar os encontros de todos aqueles que se lançam à obra de pensar e promover uma outra realidade.

\title{
Demons and pranks in the kingdom of the Leviathan
}

\begin{abstract}
The main objective of this paper - resulting from an academic speech at UFG (Universidade Federal de Goiás) -is to outline the importance of Thomas Hobbes' most known political work: Leviathan. Taking the figure of a big marine monster, quite in the same sense of the biblical metaphor used in the dialogue between God and Job to introduce the danger or the benefit of a big power controlled by men, Hobbes's arguments terrorized the Church but helped in creating new ways of thinking so to conceive the modern state. In the same movement, many other "demons" emerged to fight against religious power and also other forms of totalitarianism. Nevertheless, even shocking our conventional assumptions, Hobbes' political work may be considered - among other liberal thinkers - a defense of individualism and many other aspects of civil order, which make him one of the most important contributor to modernity and also an essential source to think about our reality.
\end{abstract}

Key words: Hobbes, Leviathan, modern state, politics.

\section{NOTAS}

1 Os termos gregos e suas significações são citados por BOFF, Leonardo. O despertar da Águia.

2 Expressão criada por Kant (1724-1804) para as questões morais. Representa um princípio objetivo que possa ser aplicado universalmente. Um dever que atinja a todos como uma espécie de regra de ouro a fim de evitar o relativismo moral, o utilitarismo e até o autoritarismo.

3 "O preceito de agir com os outros, como queremos que ajam conosco, só tem como alicerce real a consciência”.(Emílio, p. 261, nota 4). 


\section{REFERÊNCIAS}

AQUINO, Tomás de. Seleção de textos. São Paulo: Editora Nova Cultural, 2004. (Coleção Os Pensadores)

BÍBLIA, Português. BÍBLIA Sagrada. Tradução de João Ferreira de Almeida. 2" ed. rev., 6" impressão. São Paulo: Geográfica, 2000.

BOFF, Leonardo. O despertar da águia: o dia-bólico e o simbólico na construção da realidade. $1^{2}$. ed. Petrópolis, RJ: Vozes, 2001.

BOURDIEU, Pierre. Leitura, leitores, letrados, literatura. In: 1990.

Coisas ditas. São Paulo: Editora Brasiliense, p. 134-146,

CONCISO DICIONÁRIO BÍBLICO. Por diversos autores americanos e ingleses. Traduzido e ampliado por D. Ana e Dr. S. L. Watson. 28 edição. Rio de Janeiro: Imprensa Bíblica Brasileira, 2000.

FREIRE, Paulo. Pedagogia da autonomia: saberes necessários á prática educativa. 17ª ed., São Paulo: Paz e Terra, 2001.

FUKUYAMA, Francis. The end of history and the last man. New York: Avon Books, 1998.

GADOTTI, Moacir. Educar para um outro mundo possível: o Fórum Social Mundial como espaço de aprendizagem de uma nova cultura política e como processo transformador da sociedade civil planetária (apostila impressa).

GRAMSCI, Antonio. Os intelectuais e a organização da cultura. 7a ed., Rio de Janeiro: Civilização Brasileira, 1989. 
HARDT, Michael; NEGRI, Antonio. Império. Rio de Janeiro: Record, 2001.

. Multidão: guerra e democracia na era do Império. Rio de Janeiro: Record, 2005.

HARZARD, Paul. O pensamento europeu no século XVIII (de Montesquieu a Lessing). Tradução Carlos Grifo Babo. Lisboa: Editorial Presença; São Paulo: Martins Fontes, 1978. (Coleção Síntese)

HECK, José N. Thomas Hobbes: passado e futuro. $1^{\mathrm{a}}$. reimpressão, Goiânia: Editora da UFG, 2004.

HOBBES, Thomas. Leviathan. Edited with an introduction and Notes by J. C. A. Gaskin. New York: Oxford University Press, 1996.

. Do cidadão. Tradução, apresentação e notas de Renato Janine Ribeiro. 3a. ed. São Paulo: Martins Fontes, 2002. (Clássicos)

HOLLOWAY, John. Mudar o mundo sem tomar o poder: o significado da revolução hoje. Tradução de Emir Sader. São Paulo: Viramundo: 2003.

HOLY BIBLE. King James Version, 1611. New York: American Bible Society, 1996.

KANT, Immanuel. The critique of Pure Reason; The critique of Practical Reason and other ethical treatises; The critique of Judgement. 21st printing. Chicago: The University of Chicago/Encyclopaedia Britannica, Inc., 1977.

MACPHERSON, Crawford B. A teoria política do individualismo possessivo de Hobbes até Locke. Trad. Nelson Dantas. Rio de Janeiro: Paz e Terra, 1979. 
MARX, Karl. Manuscritos econômico-filosóficos. S. Paulo: Martin Claret, 2003. (Coleção A obra prima de cada autor, n. 68).

PAIVA, Wilson Alves de. Embate político na Idade Média e as idéias de Guilherme de Ockham. Revista Estudos, v. 32, n. ${ }^{0}$ 7, p. 1289-1308, 2005.

. O Emílio e a formação do cidadão do mundo moderno. 2005. Dissertação de Mestrado. Universidade Federal de Goiás.

PATOMÄKI, Heikki; TEIVAINEN, Teivo. A possible world: democratic transformation of global institutions. New York: Zed Books, 2004.

RIBEIRO, Renato Janine. Civilização sem guerra. In: NOVAES, Adauto (org.). Civilização e barbárie. São Paulo: Companhia das Letras, 2004.

ROUSSEAU, Jean-Jacques. Oeuvres complètes. 4 volumes, Paris: Gallimard, 1964. (Bibliothéque de la Plêiade).

. Emílio ou da educação. $2^{\mathrm{a}}$ ed. São Paulo: Difusão Européia do Livro, 1973.

SÁ, Fernando. A ética da vontade ou a cidadania medíocre. Revista Comum, v. 5, n. 14, p. 78-102, 2000.

STRIKE, Knneth. Liberal justice and the marxist critique of education: a study of conflicting research programs. New York/London: Routledge, 1989.

TEIVAINEN, Teivo. Pedagogia del poder mundial: relaciones internacionales y lecciones del desarrollo en América 
latina. Peru: CEDEP - Centro de Estudios para el Desarrollo y la Participación, 2003.

TUCK, Richard. Hobbes. Tradução de Adail Ubirajara Sobral e Maria Stela Gonçalves. São Paulo: Edições Loyola, 2001. (Coleção Mestres do Pensar). 